\title{
ACCESS TO TWO DISTINCTIVE WETLANDS IN CENTRAL MANITOBA
}

FREDERICK W. SCHUELER, Herpetology Section, National Museum of Natural Sciences, National Museums of Canada, Ottawa, Ontario. K1A OM8.

In the course of herpetological field work for the National Museum of Natural Sciences, R. M. Rankin and I encountered two distinctive wetlands in central Manitoba which are relatively easily accessible from Hwy. 6 along the hydroelectric powerline to Norway House. The purpose of this communication is to draw the attention of prairie naturalists to these sites.

The powerline runs from a transformer station $2.5 \mathrm{~km}$ south of William River on Hwy. 6, east along the 15th Base Line to the shore of Playgreen Lake near Norway House (the Base Line is shown on the Grand Rapids 1:250,000 topographic map). The poles are 100 yards apart, which provides a convenient measure of distance along them, and every 10 th pole is numbered.
On the evening of 9 June 1980 we drove about a kilometre west from the highway along the track which parallels the powerline, and came to a string bog which is an extension of the north end of Baker Lake. This looked much like bogs in southern Ontario or New England - a loose mat of herbaceous vegetation floating in deep $(>1 \mathrm{~m})$ water. We were impressed by the number of sandpipers, saw a pair of Sandhill Cranes (not noted as breeding here, ${ }^{5}$ ) and collected Narrow-leaved Sundews (Drosera anglica) and Pitcher Plants (Sarracenia purpurea), which were quite common. Scoggan lists no definite record of Drosera anglica for Manitoba. ${ }^{4}$ Our specimens of these species have been deposited in the NMNS herbarium. Pitcher Plants are considered sporadic at this latitude in

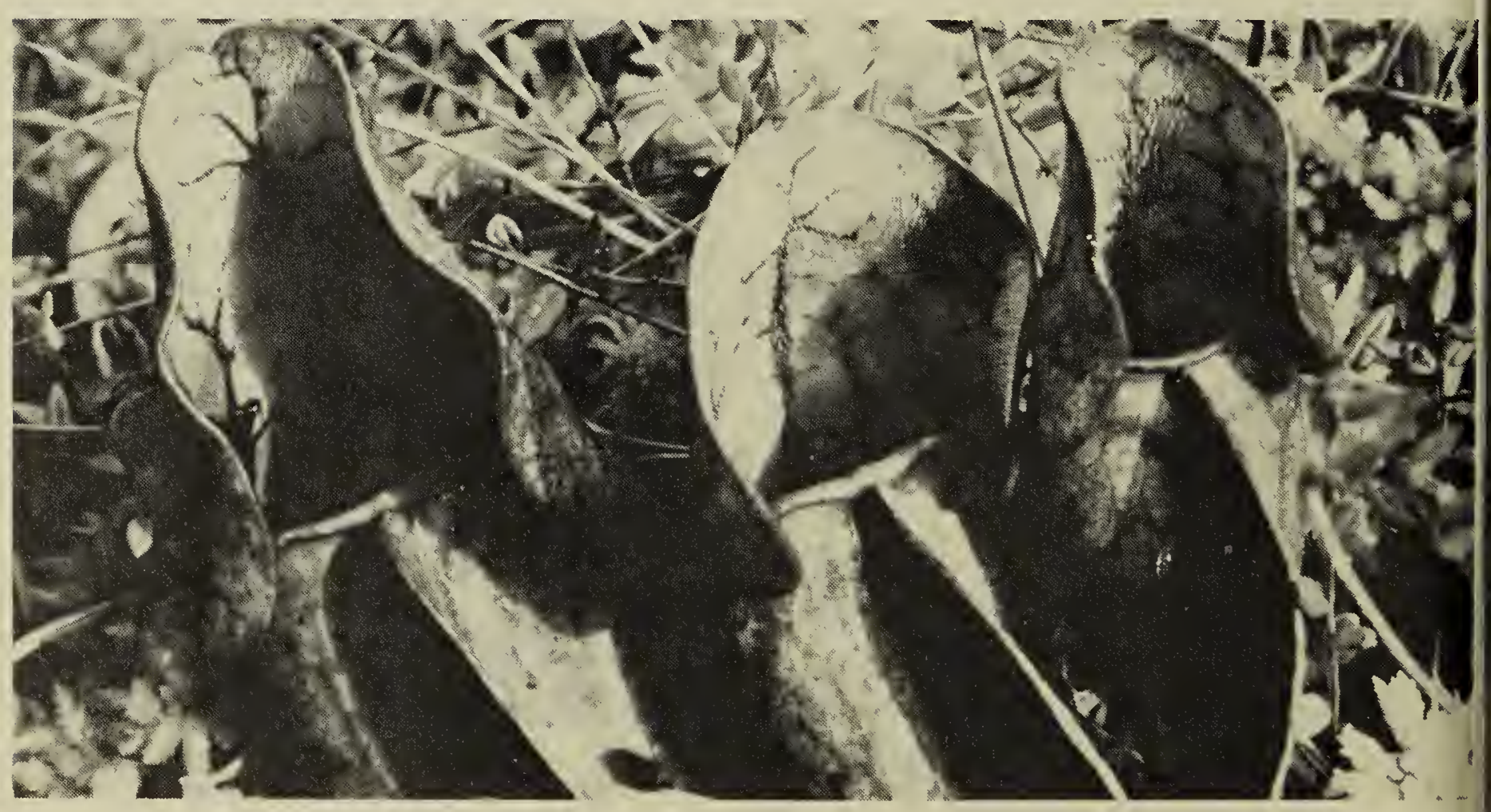

Pitcher Plant

Ken Lumbis 

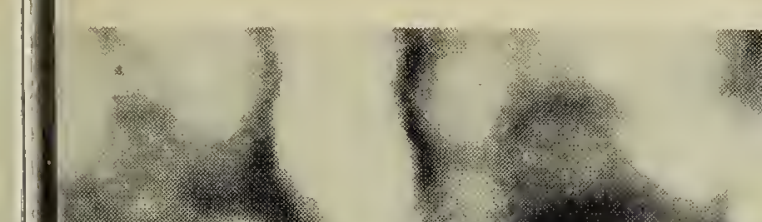

.

. 


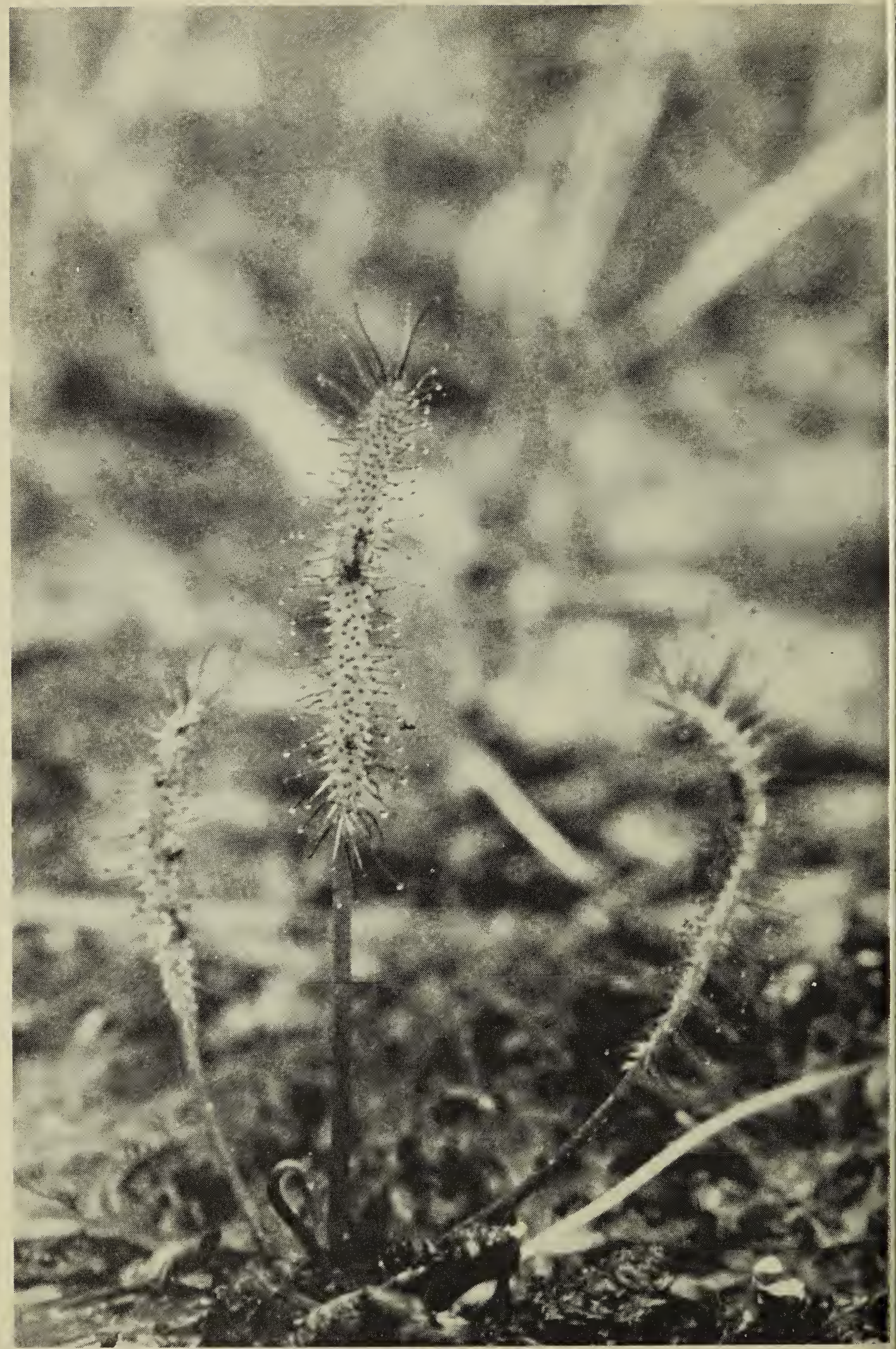


Saskatchewan. ${ }^{3}$

I planned to walk east towards the mouth of the William River at Limestone Bay, searching for toads, and set out before dusk, crossing the string bog on game trails north of the powerline. I went along the line across an area of sparse Jack Pine and into a broad sedge bog that extended about a kilometre to another upland area. Beyond this, spruce, muskeg and forest extends 15 $\mathrm{km}$ to the William River near Limestone Bay. The sedge bog was of solid peat 1$\mathrm{m}$ deep over bedrock. There was no pen water, and the uniform vegetation f short sedges and cottongrass eminded me of the shores of James Bay. ${ }^{3}$ I disturbed about three pairs of ranes on my way east, and on the way back I saw a calling Yellow Rail. The atter species has been found in similar ites. ${ }^{3}$ I heard several other Yellow Rails and Savannah Sparrows singing in the arly dawn.

Unfortunately, this night was cold and ve neither saw nor heard any mphibians and our time was limited, so we could not remain any longer. The presence of Pitcher Plants ${ }^{2}$, sundew ${ }^{4}$, Sandhill Cranes ${ }^{5}$, and Yellow Rails ${ }^{3}$ testifies to the botanical and ornithological interest of these bogs, and their herpetology, particularly any evidence of hybridization between Canadian Toads and American Toads, such as we found at Limestone Bay remains unknown.

'COOK, F. R. in press; An analysis of toads of the Bufo americanus group in a contact zone in northern North America. NMNS Publications in Zoology.

${ }^{2}$ HARMS, V. L. 1978. The native carnivorous plants of Saskatchewan. Blue Jay 36:71-81.

${ }^{3}$ SCHUELER, F.W., D. H. BALDWIN and J. D. RISING 1974. The status of birds from selected sites in northern Ontario. Canadian Field-Naturalist 88:141-150.

${ }^{4}$ SCOGGAN, H. J. 1978. The flora of Canada, NMNS, Ottawa.

${ }^{5}$ STEPHEN, W. J. D. 1980. Where do Sandhill Cranes raise their young? Blue Jay 38:115-116.

\section{A REQUEST FOR INFORMATION ON PRIVATE HERBARIA IN SASKATCHEWAN}

The Fort Qu'Appelle Herbarium is at present preparing a list of Saskatchewan Herbaria and wishes to know of the existence of private herbaria or plant collections, large or small. Additional information such as year founded, number of specimens, special interests, exchange of specimens, etc. will be greatly appreciated. - Bernard de Vries, Botanist, Fort Qu'Appelle Herbarium, Fort Qu'Appelle, Saskatchewan. SOG 1 SO. 